EDUTECH : Jurnal Inovasi Pendidikan Berbantuan Teknologi

Vol. 2 No. 1 Februari 2022, e-ISSN : 2797-0140 | p-ISSN : 2797-0590

\title{
UPAYA PENINGKATAN MINAT DAN HASIL BELAJAR SISWA MENGGUNAKAN MULTIMEDIA PEMBELAJARAN INTERAKTIF IPA DI KELAS VI SDN 015 SUNGAI BENGKAL
}

\author{
SUHARTI \\ SD Negeri 015/VIII Sungai Bengkal Kabupaten Tebo Provinsi Jambi \\ suharikarim76@gmail.com
}

\begin{abstract}
ABSTRAK
Penelitian ini bertujuan untuk 1) Mendeskripsikan pembelajaran IPA dengan multimedia sebagai upaya meningkatkan minat belajar siswa di Kelas VI SDN 015 Sungai Bengkal 2) Mendeskripsikan pembelajaran IPA dengan multimedia dalam meningkatkan hasil belajar siswa di Kelas VI SDN 015 Sungai Bengkal. Penelitian ini dilaksanakan di SDN 015 Sungai Bengkal, Kabupaten Tebo selama periode semester Ganjil tahun pelajaran 2019/2020. Pengambilan data secara diskriptif kualitatif dengan jenis penelitian tindakan kelas (PTK). Hasil penelitian menunjukkan bahwa dengan multimedia dapat meningkatkan minat dan hasil pembelajaran IPA Kelas VI SDN 015 Sungai Bengkal. Peningkatan ini dibuktikan tahap pratindakan, menunjukkan bahwa hasil belajar siswa kelas VI pada mata pelajaran IPA tergolong rendah. Nilai rata-rata kelas mencapai 65,94 sedangkan ketuntasan belajar sebesar 44\%. Pada siklus I minat belajar siswa mencapai $73 \%$ sedang rata-rata hasil belajar siswa 69,81 . Pada siklus II minat belajar siswa meningkat menjadi $85 \%$ sudah memenuhi indikator dari minat belajar siswa yaitu $80 \%$ sedangkan nilai hasil belajar siswa 77,70. Hasil belajar pada siklus II telah memenuhi indikator keberhasilan karena dari $\leq 75 \%$ siswa sudah mencapai KKM.
\end{abstract}

Kata Kunci: minat belajar, hasil belajar, multimedia pembelajaran interaktif IPA

\section{ABSTRACT}

This study aims to 1) Describe science learning with multimedia as an effort to increase student interest in learning in Class VI SDN 015 Sungai Bengkal 2) Describe science learning with multimedia in improving student learning outcomes in Class VI SDN 015 Sungai Bengkal. This research was conducted at SDN 015 Sungai Bengkal, Tebo Regency during the Odd semester period of the 2019/2020 school year. Descriptive qualitative data collection with the type of classroom action research (CAR). The results showed that multimedia could increase interest and learning outcomes in Science Class VI SDN 015 Sungai Bengkal. This increase is evidenced by the pre-action stage, indicating that the learning outcomes of grade VI students in science subjects are low. The average value of the class reached 65.94 while learning completeness was $44 \%$. In the first cycle students' interest in learning reached $73 \%$, while the average student learning outcomes was 69.81. In the second cycle, the student's interest in learning increased to $85 \%$, already meeting the indicators of the student's interest in learning, namely $80 \%$, while the value of student learning outcomes was 77.70 . The learning outcomes in cycle II have met the indicators of success because of $\leq 75 \%$ of students have reached the KKM.

Keywords: interest in learning, learning outcomes, interactive science learning multimedia

\section{PENDAHULUAN}

Pendidikan merupakan salah satu bagian penting dalam kehidupan umat manusia. Pendidikan berfungsi untuk mengembangkan sumber daya manusia yang berorientasi meningkatkan kualitas kehidupan. Pendidikan tidak semata-mata berusaha untuk mencapai hasil belajar, tetapi bagaimana memperoleh hasil atau proses belajar yang terjadi pada diri anak. Suasana belajar dan pembelajaran itu diarahkan agar peserta didik dapat mengembangkan potensi dirinya, ini berarti proses pendidikan itu harus berorientasi kepada siswa (student active learning) (Desstya, dkk, 2017). Akhir dari proses pendidikan adalah kemampuan anak memiliki kekuatan spiritual keagamaan, pengendalian diri, kepribadian, kecerdasan, akhlak mulia, serta 
keterampilan yang diperlukan dirinya, masyarakat, bangsa, dan negara. Hal ini berarti proses pendidikan berujung kepada pembentukan sikap, pengembangan kecerdasan atau intelektual, serta pengembangan keterampilan anak sesuai dengan kebutuhan (Ananda, dkk, 2018).

Menurut Sardiman (2012) minat belajar adalah keseluruhan daya penggerak didalam diri siswa yang menimbulkan kegiatan belajar, yang menjamin kelangsungan dari kegiatan belajar dan memberikan arah pada kegiatan belajar, sehingga tujuan yang dikehendaki oleh subjek belajar itu dapat tercapai. Minat belajar akan mendorong siswa untuk belajar dengan giat, memberikan arah pada kegiatan belajarnya sehingga tujuan belajarnya akan tercapai. Minat belajar merupakan merupakan faktor psikis yang bersifat non intelektual dan berperan dalam hal menumbuhkan semangat belajar untuk individu. Lengkapnya dapat disimpulkan bahwa pengertian minat belajar adalah keseluruhan daya penggerak baik dari dalam diri maupun dari luar siswa (dengan menciptakan serangkaian usaha untuk menyediakan kondisikondisi tertentu) yang menjamin kelangsungan dan memberikan arah pada kegiatan belajar, sehingga tujuan yang dikehendaki oleh subjek belajar itu dapat tercapai (Fauziah, dkk, 2017). Jadi proses pembelajaran akan semakin produktif jika siswa memiliki minat belajar yang tinggi. Minat akan mendorong siswa untuk belajar dengan giat sehingga meningkatkan Hasil belajarnya (Tafonao, 2018).

Menurut Nurhasanah (2016) menyatakan bahwa Hasil belajar merupakan sesuatu yang dibutuhkan seseorang untuk mengetahui kemampuan setelah melakukan kegiatan yang bersifat belajar, karena Hasil adalah hasil belajar yang mengandung unsur penilaian, hasil usaha kerja dan ukuran kecakapan yang dicapai suatu saat. Hasil belajar IPA dapat diketahui dari hasil belajar siswa dalam mengerjakan soal evaluasi pada mata pelajaran IPA. Hasil belajar merupakan perubahan yang terjadi pada diri siswa baik yang menyangkut aspek, kognitif, afektif, dan psikomotor sebagai hasil dari kegiatan belajar (Riwahyudin, 2015). Berdasarkan beberapa pendapat diatas dapat disimpulkan bahwa Hasil belajar merupakan hasil yang dicapai oleh individu setelah mengalami proses belajar dalam jangka waktu tertentu. Hasil belajar yang ditampilkan dengan nilai atau angka dibuat guru berdasarkan pedoman penilaian pada masingmasing siswa berbeda, berdasarkan tingkat penguasaan kompetensi yang telah ditetapkan. Faktor-faktor yang mempengaruhi Hasil belajar adalah 1) Faktor-faktor dalam diri individu meliputi: a) Aspek jamaniah mencakup kondisi dan kesehatan jasmani dari individu, b) Aspek psikis atau rohaniah individu, c) Kondisi intelektual individu, d) Kondisi sosial menyangkut hubungan dengan orang lain, e) Minat belajar yang kuat, dan f) Keterampilan-keterampilan yang dimilikinya. 2) Faktorfaktor lingkungan, keberhasilan belajar juga sangat dipengaruhi oleh faktor-faktor di luar diri siswa, baik faktor fisik maupun sosial-psikologis yang berada pada lingkungan keluarga, sekolah, dan masyarakat (Sobron, dkk, 2019).

Kenyataan selama ini masih banyak penggunaan model serta metode pembelajaran yang masih bersifat konvensional, belum adanya improvisasi menjadi pembelajaran yang modern sesuai dengan tuntutan zaman dan lingkungan sekitar dimana siswa berada. Guru kelas dalam menyampaikan materi masih belum menggunakan media pembelajaran (Kadarisma, dkk, 2019). Dalam penyampaian materi guru masih dominan menggunakan metode ceramah atau penyampaian materi secara verbal. Selama proses pembelajaran yang telah berlangsung, siswa merasa kesulitan memahami materi yang sifatnya abstrak. Selain itu, guru masih kurang aktif melibatkan siswa dalam proses pembelajaran, sehingga kompetensi afektif siswa belum tercapai sepenuhnya. Pada awal pembelajaran siswa masih memperhatikan, menjelang pertengahan terlihat siswa cenderung bosan mengikuti pelajaran. Untuk itu perlu adanya pembaharuan agar proses dan hasil pembelajaran bisa mencapai tujuan yang optimal, salah satu caranya adalah penggunaan multimedia pembelajaran agar materi pembelajaran bisa lebih konkrit (Krismanto, 2016). Penerapam ICT dalam pembelajaran di era perkembangan teknologi yang semakin pesat merupakan sebuah keniscayaan (Novita \& Fazriani, 2019). Beberapa contoh model pembelajaran yang modern yang cocok digunakan dalam pembelajaran IPA di antaranya model pembelajaran contextual teaching and learning, cooperative learning, quantum 
learning, active learning, serta teknologi dan masyarakat (Nurdiansyah, 2018). Beberapa model pembelajaran tersebut sebagai upaya pembaharuan dalam pembelajaran IPA.

Proses penyampaian materi pada pembelajaran IPA di kelas VI SDN 015 Sungai Bengkal menggunakan multimedia berbasis powerpoint. Multimedia adalah suatu sistem penyampaian pesan menggunakan berbagai jenis pengajaran yang membentuk suatu unit atau paket (Hidayati, 2017). Contoh dari multimedia adalah satu modul pembelajaran yang terdiri atas bahan cetak, bahan audio, dan bahan audiovisual yang dikemas dalam satu paket. Multimedia berbasis powerpoint didalamnya meliputi objek teks, gambar, video dan hyperlink yang digunakan secara terintegrasi. Penggabungan objek-objek tersebut akan menjadi satu kesatuan atau terintegrasi antara satu sama lain dalam proses pembelajaran di kelas. Dalam menyajian materi IPA secara verbal menggunakan metode ceramah dan secara pictorial menggunakan proyeksi grafis yang meliputi gambar dan video (Piyayodilokchai et., al, 2013). Multimedia berbasis powerpoint ini digunakan untuk menjelaskan materi-materi yang bersifatnya teoritis dalam pembelajaran klasikal, baik untuk kelompok kecil maupun besar (Nugraheni, dkk, 2018). Seperti yang kita ketahui pada umumnya mata pelajaran IPA memiliki materi yang cenderung sebagian abstrak dan nyata, bersifat teoritis dan praktis. Apabila guru dalam menyampaikan materi hanya menggunakan metode ceramah saja, pasti akan membuat siswa menjadi cepat bosan. Multimedia ini cukup efektif sebab menggunakan media projector (LCD/ Viewer) yang memiliki jangkauan pancar cukup besar apabila dipasang di dalam kelas. Proses pembelajaran demikian itu, dapat membuat siswa yang duduk di depan sampai paling belakang akan memperhatikan proses pembelajaran

Hasil survei bulan Agustus 2019 kepada siswa kelas VI di SDN 015 Sungai Bengkal, menunjukkan bahwa para siswa tersebut merasa kesulitan belajar IPA karena pembelajaran cenderung berupa pemahaman dan cakupan materi yang luas. Minat siswa dalam pembelajaran masih rendah sehingga siswa mengalami kesulitan dalam belajar. Kesulitan belajar siswa juga dipengaruhi oleh beberapa faktor seperti kurang konsentrasinya siswa saat belajar, siswa terlihat berbicara sendiri saat pembelajaran berlangsung dan ada siswa yang senang menjaili teman sebangkunya saat pelajaran berlangsung. Jika keadaan ini dibiarkan terus menerus akan membuat siswa yang bersangkutan ketinggalan pelajaran dan berdampak pada hasil belajarnya. Berdasarkan hasil belajar siswa di kelas VI di SDN 015 Sungai Bengkal menunjukkan para siswa merasa kesulitan dalam pembelajaran IPA. Sedangkan Hasil belajar IPA kelas VI masih rendah jika dibandingkan dengan mata pelajaran lain seperti PKn, Bahasa Indonesia, Matematika, dan IPS. Dikatakan Hasil belajar rendah, karena ditunjukkan dari nilai rata-rata siswa kelas VI dengan jumlah 27 siswa, yang terdiri dari siswa perempuan yang berjumlah 16 dan siswa laki-laki 11 untuk pelajaran IPA nilai rata-rata 65,94 belum mencapai KKM. Dimana KKM yang ditetapkan untuk pelajaran IPA kelas VI di SDN 015 Sungai Bengkal adalah 70. Untuk mengatasi masalah tersebut guru harus mampu menciptakan pembelajaran yang menarik dan menyenangkan agar siswa memiliki minat belajar yang tinggi. Salah satu cara untuk menumbuhkan minat siswa adalah dengan menggunakan multimedia dalam pembelajaran. Dengan multimedia diharapkan siswa dapat lebih konkrit dalam pembelajaran IPA yang berifat teoritis dan praktis. Dengan multimedia siswa terminat dan merasa senang dalam mengikuti pembelajaran, sehingga dapat mencapai Hasil belajar yang maksimal. Penggunaan multimedia pembelajaran akan memberikan pengalaman belajar secara nyata bagi siswa kelas VI SD dengan disertai teks, gambar, video, dan hyperlink sehingga pembelajaran jauh lebih menarik dan bermakna. Jika menggunakan multimedia maka dapat meningkatkan minat dan Hasil belajar siswa pada pembelajaran IPA.

\section{METODE PENELITIAN}

Penelitian ini dilaksanakan di SDN 015 Sungai Bengkal, Kabupaten Tebo Provinsi Jambi. Penelitian ini dilaksanakan selama semester ganjil tahun pelajaran 2019/2020 di SDN 015 Sungai Bengkal, Kabupaten Tebo Provinsi Jambi. Pada penelitian ini, peneliti berusaha mendeskripsikan bentuk pembelajaran untuk meningkatkan pemahaman siswa dengan 
menerapkan pembelajaran IPA berbasis multimedia pada materi perkembangbiakan generatif pada tumbuhan, maka dengan demikian data yang akan dikumpulkan dalam penelitian bersifat deskriptif yaitu mengenai uraian-uraian kegiatan pembelajaran siswa dan penelitian ini menggunakan pendekatan kualitatif dengan jenis penelitian tindak kelas. Subyek penelitian ini adalah siswa kelas VI di SDN 015 Sungai Bengkal, Kabupaten Tebo Provinsi Jambi semester ganjil tahun pelajaran 2019/2020 yang berjumlah 27 siswa yang terdiri 11 laki-laki dan 16 perempuan.

Teknik pengumpulan data yaitu observasi, tes, catataan lapangan, dan dokumentasi. Sedangkan penelitian tindakan kelas ini menggunakan model tindakan yang dikembangkan oleh Kemmis, McTaggart, danNixon (2013), yang meliputi empat komponen yaitu: perencanaan (planning), tindakan (acting), pengamatan (observing), dan refleksi (reflecting). Untuk menentukan keberhasilan penelitian ini dibutuhkan indikator kinerja penelitian yaitu 1) Kemauan, kemampuan, dan aktivitas dalam melaksanakan pembelajaran IPS dengan menggunakan multimedia, menyusun laporan, mempresentasi, dan berdiskusi. 2) Pemahaman konsep siswa dengan menggunakan multimedia dalam pembelajaran IPA. 3) $80 \%$ siswa terminat dalam belajar. 4) $75 \%$ siswa tuntas belajar. Dalam pelaksanakan PTK ini analisis data dibedakan menjadi dua jenis yaitu: 1) Data Kuantitatif yaitu data yang berhubungan dengan minat belajar dengan perhitungan persentase. 2) Data Kualitatif digunakan untuk menentukan peningkatan proses belajar khususnya berbagai tindakan yang dilakukan oleh guru.

\section{HASIL DAN PEMBAHASAN}

Dari observasi yang telah dilakukan diperoleh gambaran awal bahwa guru menyampaikan materi masih menggunakan metode ceramah. Kegiatan guru masih mendominasi saat proses pembelajaran IPA. Siswa jarang mendapat kesempatan untuk berbicara, alhasil komunikasi hanya berjalan satu arah. Hal ini terbukti dari hasil nilai rata-rata pra siklus yaitu ketuntasan siswa pada mata pembelajaran IPA sebanyak 12 siswa atau $44 \%$. Jumlah siswa yang belum tuntas adalah 15 atau 56\%. Minat siswa dalam mengikuti pembelajaran mencapai 59\% sedangkan hasil belajar yang diperoleh siswa sebesar 65,94. Terindikasi bahwa hasil belajar siswa pada mata pelajaran IPA kelas VI tergolong rendah, dan di bawah kriteria ketuntasan minimum yaitu KKM di SDN 015 Sungai Bengkal yaitu 70.

\section{Siklus I}

Capaian hasil pelaksanaan Siklus I, minat belajar siswa dengan multimedia mencapai 73\%, hal ini sudah mengalami peningkatan dibandingkan pada prasiklus (59\%) tetapi belum memenuhi indikator keberhasilan yang telah ditentukan yaitu $80 \%$. Perbandingan minat siswa pada prasiklus dan siklus I dapat dilihat pada gambar berikut ini:

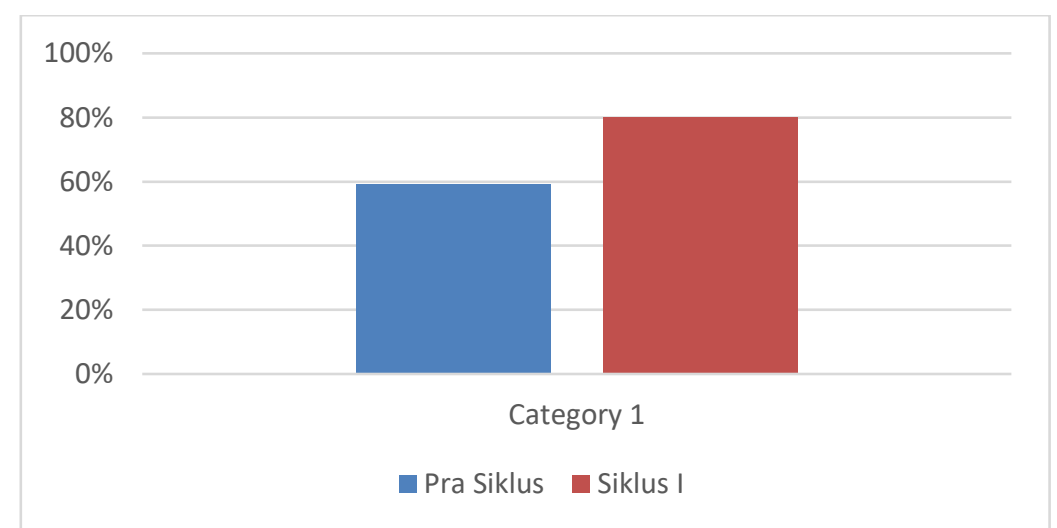

\section{Gambar 1. Perbandingan Minat Belajar Prasiklus dan Siklus I}

Sedangkan ketuntasan siswa pada mata pembelajaran IPA pada siklus I sebanyak 18 siswa atau 67\%. Jumlah siswa yang belum tuntas adalah 9 atau 33\%. Nilai rata-rata yang diperoleh siswa sebesar 69,81. Dari hasil belajar siswa pada mata pelajaran IPS kelas IV pada 
siklus I dengan menggunakan multimedia sudah adanya peningkatan terlihat dari hasil post tes siswa kelas IV persentase sudah meningkat. Tetapi masih ada beberapa siswa yang mendapat nilai di bawah kriteria ketuntasan minimum yaitu KKM. Pada prasiklus, siswa yang mencapai KKM sebanyak 12 orang (44\%) dan yang tidak tuntas sebanyak 15 orang (56\%). Sedangkan pada siklus I, siswa yang mencapai KKM sebanyak 18 orang $(67 \%)$ dan yang tidak tuntas sebanyak 9 orang (33\%). Perbandingan capaian KKM Perbandingan nilai rata-rata prasiklus dan siklus I dapat digambarkan seperti di bawah ini:

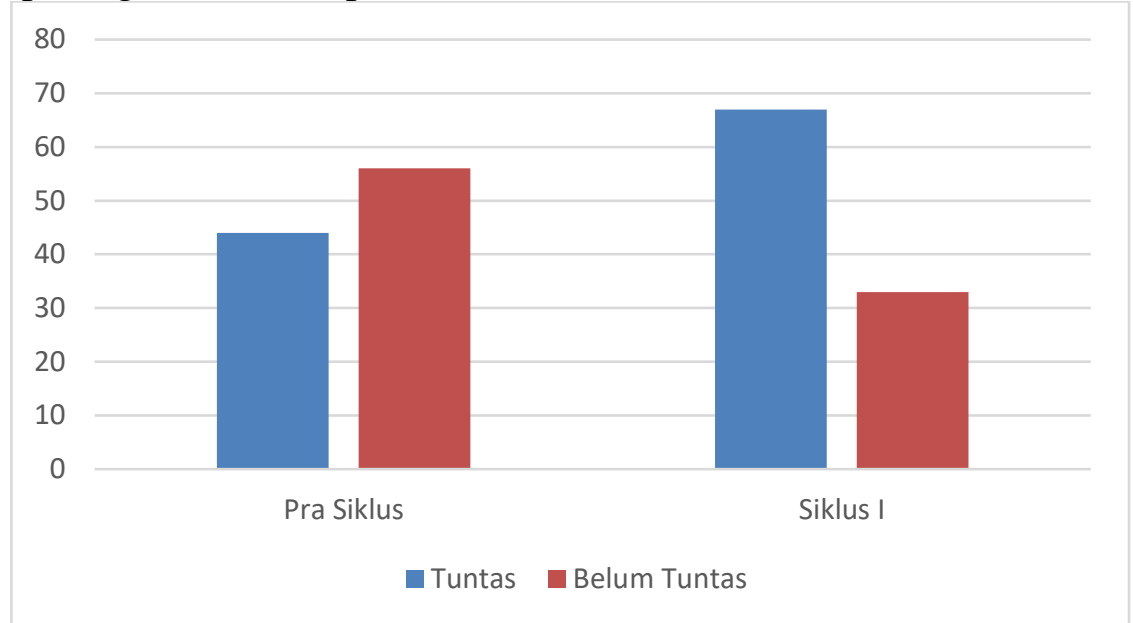

\section{Gambar 2. Perbandingan Capaian KKM Prasiklus dan Siklus I}

\section{Siklus II}

Siklus II pertemuan pertama dilaksanakan pada tanggal 18 Oktober 2019. Minat siswa dalam pembelajaran mencapai $85 \%$, hal ini sudah memenuhi indikator keberhasilan minat siswa yaitu $80 \%$. Perbandingan dan kenaikan minat pada siklus I dan siklus II tersebut dapat digambarkan seperti di bawah ini:

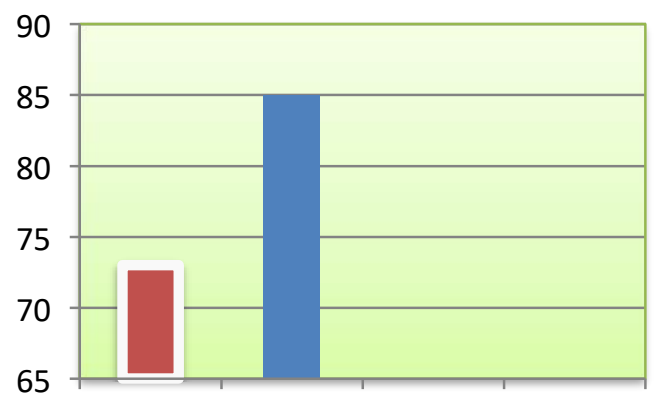

\section{Gambar 3. Perbandingan Minat Belajar Siklus I dan Siklus II}

Ketuntasan siswa pada mata pembelajaran IPS sebanyak 22 siswa atau 81\%. Jumlah siswa yang belum tuntas adalah 5 atau 19\%, nilai rata-rata yang diperoleh siswa sebesar 77,70. Tingkat ketuntasan klasikal sebesar $81 \%$ tersebut di atas sudah sesuai harapan atau karena sudah mencapai di atas indikator keberhasilan yang ditetapkan $\geq 75 \%$. Oleh karena itu penelitian berhenti pada siklus II. Perbandingan dan kenaikan nilai rata-rata siklus I dan siklus II dapat digambarkan di bawah ini: 


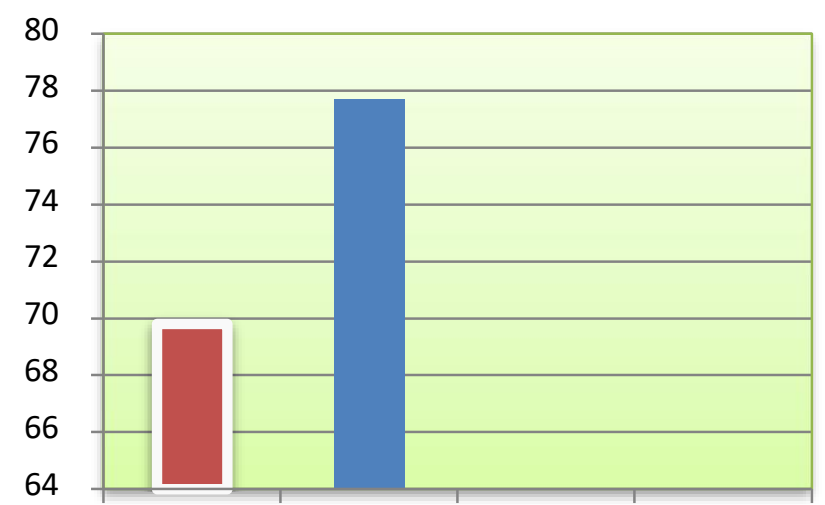

\section{Gambar 4. Perbandingan Nilai Rata-rata Siklus I dan Siklus II}

Pada siklus II, siswa yang mencapai KKM sebanyak 22 orang (81\%) dan yang tidak tuntas sebanyak 7 orang (19\%). Sedangkan pada siklus I, siswa yang mencapai KKM sebanyak 18 orang $(67 \%)$ dan yang tidak tuntas sebanyak 9 orang $(33 \%)$. Perbandingan capaian KKM tersebut dapat digambarkan seperti di bawah ini:

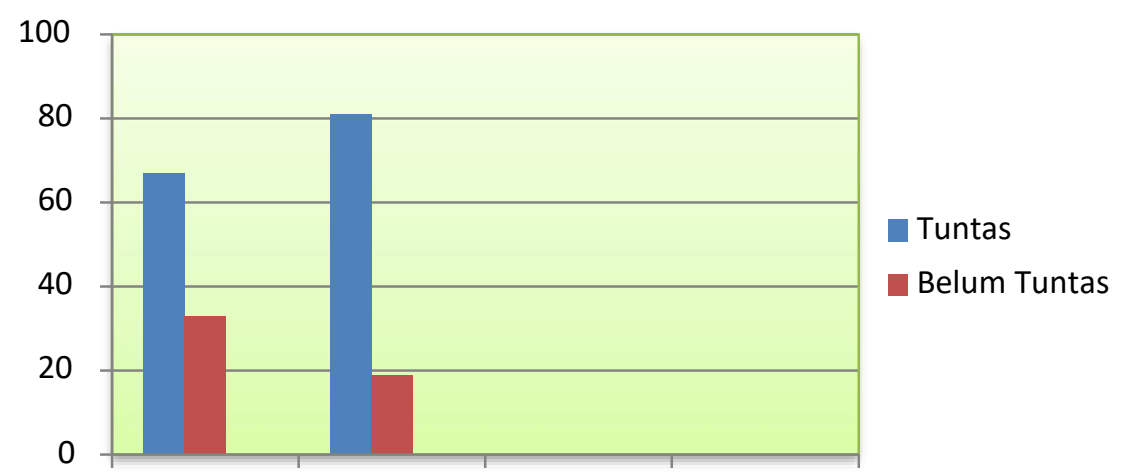

Gambar 5. Perbandingan Capaian KKM Siklus I dan Siklus II

Dari hasil pelaksanaan tindakan penelitian sebagaimana disampaikan di atas menunjukkan bahwa penggunakan multimedia dapat meningkatkan minat dan hasil belajar siswa Kelas VI SDN 015 Sungai Bengkal. Minat belajar siswa pada prasiklus 59\%, siklus I $73 \%$ dan siklus II $85 \%$. Persentase minat belajar siswa seperti di atas dapat ditunjukkan dalam gambar di bawah ini:

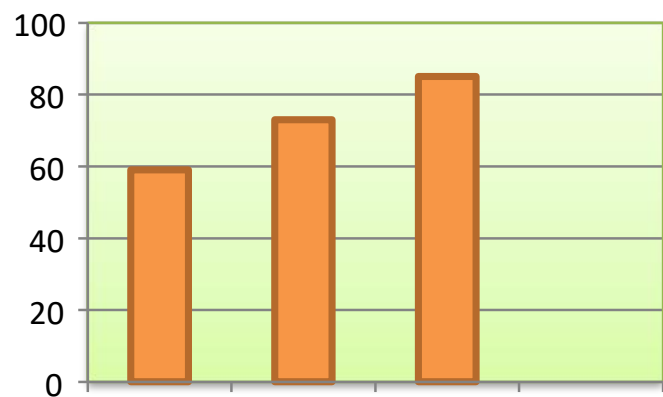

Motivasi Siswa Prasiklus,Siklus I dan siklus II

\section{Gambar 6. Persentase Minat Siswa Prasiklus, Siklus I dan Siklus II}

Sedangkan nilai hasil belajar yang diraih siswa dari prasiklus $(65,94)$, siklus I $(69,81)$ dan siklus II $(77,70)$ mengalami peningkatan. Persentase nilai rata-rata klasikal seperti di atas dapat ditunjukkan dalam gambar di bawah ini: 


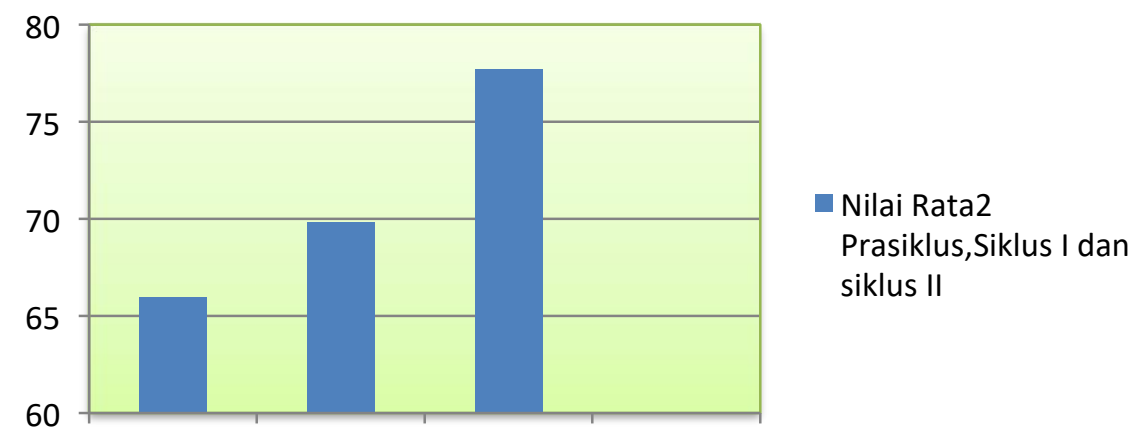

Gambar 7 Persentase Nilai Rata2 Prasiklus, Siklus I dan Siklus II

Siswa yang mencapai nilai di atas atau sama dengan Kriteria Ketuntasan Minimal (KKM) sebelum pemberian tindakan sampai dengan pemberian tindakan (siklus I dan siklus II) mengalami kenaikan, sebaliknya siswa yang tidak mencapai KKM mengalami penurunan. Hal tersebut dapat dilihat pada tabel di bawah ini:

Tabel 1. Kriteria Capaian KKM Prasiklus, Siklus I dan Siklus II

\begin{tabular}{|c|c|c|c|c|c|c|c|}
\hline Kriteria & & Prasiklus & & Siklus I & & Siklus II & \\
\hline $\begin{array}{l}\text { Capaian } \\
\text { KKM }\end{array}$ & KKM & $\begin{array}{l}\text { Jumlah } \\
\text { Siswa }\end{array}$ & Persentase & $\begin{array}{l}\text { Jumlah } \\
\text { Siswa }\end{array}$ & Persentase & $\begin{array}{l}\text { Jumlah } \\
\text { Siswa }\end{array}$ & Persentase \\
\hline Tuntas & $\geq 70$ & 12 & 44 & 18 & 67 & 22 & 81 \\
\hline $\begin{array}{l}\text { Tidak } \\
\text { tuntas }\end{array}$ & $<70$ & 15 & 56 & 9 & 33 & 5 & 19 \\
\hline Jumlah & & 27 & 100 & 27 & 100 & 27 & 100 \\
\hline
\end{tabular}

Pemanfataan multimedia dalam pembelajaran berdampak positif terhadap minat dan hasil belajar siswa (Candra \& Masruri, 2015; Fanny \& Suardiman, 2013; Mardalena, 2018). Penggunaan multimedia pada siklus II berjalan lebih baik dibandingkan pada siklus I guru sudah mengaplikasikan hasil rekomendasi dari refleksi siklus I. Hal yang dilakukan dengan cara memodifikasi media, memperbaiki kualitas gambar, video, dan hyperlink. Sedangkan kegiatan pembelajaran yang diperbaiki dari pembentukan kelompok dengan cara disamaratakan kemampuan akademik siswa, pemberian reward dan penugasan. Data yang dihasilkan pada siklus II ternyata sudah memenuhi indikator keberhasilan penelitian, sehingga penelitian tidak perlu dilanjutkan ke siklus berikutnya.

\section{KESIMPULAN}

Berdasarkan hasil penelitian dan pembahasan yang di kemukakan, simpulan yang dapat diambil dalam penelitian ini adalah penggunaan multimedia pembelajaran interaktif dapat meningkatkan minat dan hasil belajar siswa dalam pembelajaran IPA pada siswa Kelas VI SDN 015 Sungai Bengkal. Tahap pratindakan, menunjukkan bahwa minat dan hasil belajar siswa Kelas VI SDN 015 Sungai Bengkal pada mata pelajaran IPA tergolong rendah. Minat belajar mencapai 59\%, nilai rata-rata kelas mencapai 65,94 sedangkan ketuntasan belajar sebesar $44 \%$. Pada siklus I, minat siswa mencapai $73 \%$, nilai rata-rata siswa 69,81 sedangkan ketuntasan belajar siswa mengalami peningkatan sebesar 23\% (kondisi awal $44 \%$ meningkat menjadi $67 \%$ ). Pada siklus II, dengan adanya perbaikan dan modifikasi multimedia pembelajaran, disertai manajemen pembentukan kelompok dan pemberian reward, minat belajar siswa mencapai $85 \%$, nilai rata-rata siswa 77,70 dan ketuntasan belajar siswa mencapai $81 \%$. Hasil belajar pada siklus II telah memenuhi indikator keberhasilan karena dari $\leq 75 \%$ siswa sudah mencapai KKM yaitu 70. 


\section{DAFTAR PUSTAKA}

Ananda, R., \& Fadhilaturrahmi, F. (2018). Analisis Kemampuan Guru Sekolah Dasar dalam Implementasi Pembelajaran Tematik di SD. Jurnal Basicedu, 2(2), 11-21.

Candra, A. A., \& Masruri, M. S. (2015). Pengembangan multimedia interaktif dengan pendekatan saintifik untuk pembelajaran PKn SMP. Harmoni Sosial: Jurnal Pendidikan IPS, 2(2), 109-114.

Desstya, A., Novitasari, I. I., Razak, A. F., \& Sudrajat, K. S. (2017). Refleksi pendidikan IPA sekolah dasar di Indonesia (relevansi model pendidikan Paulo Freire dengan pendidikan IPA di sekolah dasar). Profesi Pendidikan Dasar, 4(1), 1-11.

Fauziah, A., Rosnaningsih, A., \& Azhar, S. (2017). Hubungan antara minat belajar dengan minat belajar siswa kelas IV SDN Poris Gaga 05 kota Tangerang. Jurnal Jpsd, 4(1), 47-53.

Hidayati, N. (2017). Efektivitas pembelajaran menggunakan multimedia interaktif (adobe flash CS6) terhadap hasil belajar matematika siswa kelas V SD N Jurug Sewon. Trihayu: Jurnal Pendidikan Ke-SD-an, 3(3).

Kadarisma, G., \& Ahmadi, Y. (2019). Pelatihan Penggunaan Media Pembelajaran Berbasis ICT Kepada Guru Sekolah Dasar. Amal Ilmiah: Jurnal Pengabdian Kepada Masyarakat, 1(1), 35-40.

Krismanto, W. (2016). Peran Pengembang Teknologi Pembelajaran Dalam Percepatan Proses Difusi Inovasi Pembelajaran.

Novita, L., Windiyani, T., \& Fazriani, R. (2019). Pengembangan media pembelajaran berbasis ict pada subtema bersyukur atas keberagaman untuk siswa kelas iv sekolah dasar. Jurnal Pendidikan dan Pengajaran Guru Sekolah Dasar (JPPGuseda), 2(2), 82-86.

Mardalena, D. (2018). Penerapan Model Pembelajaran Role Playing untuk Meningkatkan Hasil Belajar IPA Siswa Kelas VI Sekolah Dasar. Primary: Jurnal Pendidikan Guru Sekolah Dasar, 7(1), 128-136.

Nugraheny, D., Wintolo, H., \& Kusumaningrum, A. (2018). Pendampingan Pembuatan Bahan Ajar Berbasis Multimedia Menggunakan Macromedia Flash Bagi Para Guru SD IT Salsabila Al Muthi'in, Yogyakarta. KACANEGARA Jurnal Pengabdian pada Masyarakat, 1(1), 23-28.

Nurdyansyah, N. (2018). Pengembangan Bahan Ajar Modul Ilmu Pengetahuan Alambagi Siswa Kelas Iv Sekolah Dasar. Universitas Muhammadiyah Sidoarjo.

Nurhasanah, S., \& Sobandi, A. (2016). Minat belajar sebagai determinan hasil belajar siswa. Jurnal Pendidikan Manajemen Perkantoran (JPManper), 1(1), 128-135.

Piyayodilokchai, H., Panjaburee, P., Laosinchai, P., Ketpichainarong, W., \& Ruenwongsa, P. (2013). A 5E learning cycle approach-based, multimedia-supplemented instructional unit for structured query language. Journal of Educational Technology \& Society, 16(4), 146-159.

Riwahyudin, A. (2015). Pengaruh sikap siswa dan minat belajar siswa terhadap hasil belajar IPA siswa kelas V sekolah dasar di Kabupaten Lamandau. Jurnal pendidikan dasar, 6(1), 11-23.

Sardiman, A. M. (2012). Interaksi dan Minat Belajar Mengajar. Jakarta: PT Raja Grafindo Persada.

Sobron, A. N., Bayu, B., Rani, R., \& Meidawati, M. (2019, October). Pengaruh daring learning terhadap hasil belajar IPA siswa Sekolah Dasar. In Seminar Nasional Sains \& Entrepreneurship (Vol. 1, No. 1).

Tafonao, T. (2018). Peranan media pembelajaran dalam meningkatkan minat belajar mahasiswa. Jurnal Komunikasi Pendidikan, 2(2), 103-11 